\title{
IAMJ
}

INTERNATIONAL

AYURVEDIC

MEDICAL JOURNAL

ISSN: 23205091

Impact Factor: 5.34

\section{A STUDY OF NIDANAS (AETIOLOGICAL FACTORS) OF TAMAKA SHWASA i.e. BRONCHIAL ASTHMA WITH AN ANALYTICAL VIEW}

\section{$\underline{\text { Tejal J. Ganvit }}{ }^{1}$, Himanshu Kanzaria ${ }^{2}$, Anamika Soni ${ }^{3}$, Surendra A. Soni ${ }^{4}$}

${ }^{1} 3^{\text {rd }}$ Year P.G. Scholar, Upgraded PG Department of Kayachikitsa, GAAC, Ahmedabad, Gujarat, India

${ }^{2}$ Lecturer Upgraded PG Department of Kayachikitsa, GAAC, Ahmedabad, Gujarat, India

${ }^{3}$ Associate Professor, Department of Kayachikitsa, SMIAS, Gandhinagar, Gujarat, India

${ }^{4}$ Professor and HOD, Upgraded PG Department of Kayachikitsa, GAAC, Ahmedabad, Gujarat, India

Corresponding Author: ganvittejal12@gmail.com

\section{https://doi.org/10.46607/iamj3208092020}

(Published online: September 2020)

Open Access

(C) International Ayurvedic Medical Journal, India 2020

Article Received: 26/08/2020 - Peer Reviewed: 10/09/2020 - Accepted for Publication: 10/09/2020

D) Check for updates

\section{ABSTRACT}

In general meaning, difficulty in breathing or shortness in breathing is termed as 'Shwasa'. As per Ayurveda Shwasa Roga is mainly caused by vitiated Vata Dosha and Kapha

Dosha. Maha- Urdhva-Chhinna-Tamaka and Kshudra are the types of Shwasa Roga. Shwasakashtata (Breathlessness), Ativege Kasate (Cough), Pinasa (Running nose), Ghurghurukam (Wheezing), Shayane Shwasa Pidita (Worsen in supine position), Asino Labhate Saukhyam (Relaxing in sitting position), Ushnabhinanditam are the symptoms of Tamaka Shwasa. Raja-Dhuma (Pollens, Smoke/fumes), Megha-Ambu-Shita-Pragvata (Seasonal changes) are triggering factors of the Tamaka Shwasa. In this condition, patient becomes incapable to do his routine work. Incidences of Bronchial Asthma have been raised in recent decades due to increased industrialization and pollution and this miserable condition can be compared with Tamaka Shwasa described in Ayurveda. In current review article an effort has been made to explain the aetiological factors (Nidana) of Shwasa Roga described in Ayurvedic classical texts with applied and morden perspective.

Keywords: Tamaka Shwasa, Nidana. 


\section{INTRODUCTION}

Tamaka Shwasa is one of the five types of disease of Shwasa Roga described in Ayu. Texts. The signs, symptoms and etiopathogenesis of Bronchial Asthma explained in modern science have a lot of similarities with the disease entity Tamaka Shwasa. The main features of Bronchial Asthma are breathlessness, chest tightness, wheezing and cough. Bronchial Asthma is a major global health problem, which can affect the population irrespective of age, sex, economic status, etc. It is very common at all ages but predominantly in early life. The prevalence of Bronchial Asthma is increasing alarmingly nowadays due to excessive pollution, overcrowding, occupational conditions, stress and poor hygiene etc. Both Ayurveda and modern medical Science agree regarding the Nidana of the disease as host factors (Nija Hetus-Dosha Dushti and Ama) and Environmental factors (Agantuj Hetus Raja, Dhuma, Pragvata, etc.). It can be easily correlated with allergic condition. Nidana Parivarjanam plays a key role in the management strategy in both sciences.

\section{Nidana Panchaka}

To know the science of disease in totality, 5 types of examination: Nidana, Poorvarupa, Rupa, Samprapti and Upashaya-Anupashaya are applied. It is unique methodology for diagnosis call "Nidana Panchaka".

\section{Nidana}

The Etiological or causative factors of the disease has been described by Acharya Charka ${ }^{2}$.

A factor which is capable of manifesting the development of disease either quickly or after a certain period of time is called Hetus ${ }^{3}$.

\section{Importance of Nidana}

According to Sushruta Acharya, to avoid causative factors is the first line of treatment in any diseases. A well-known quote "Prevention is better than cure" has been originated from Ayurveda science ${ }^{4}$.

According to Acharya Charaka a single etiological factor may produce a single disease, or many factors together may produce single disease and vice-versa ${ }^{5}$

- Nidana (aetiological factors) of Tamaka Shwasa $^{6,7}$

In Tamaka Shwasa, either one or more etiological factors in combination can cause manifestation of disease. In Ayurvedic texts, Nidanas of Tamaka Shwasa are not described separately, but the Nidana of Shwasa Roga in general are described.

These aetiology factors can be divided as Aharaja, Viharaja $\&$ other disease. This has been presented as below:

- Aharaja Nidana

Table 1: Vishishta Gunapradhana Ahara

\begin{tabular}{|c|c|c|c|c|c|}
\hline Gunapradhana Ahara & Ch. $S .^{8}$ & Su. $S .^{9}$ & A.S..$^{10}$ & A. $H^{11}$ & M.N..$^{12}$ \\
\hline Ati Ruksha (Excessive rough) & + & & & & \\
\hline Ati Katu (Excessive pungent taste) & & & & + & \\
\hline Ati Amla (Excessive sour taste) & & & + & + & \\
\hline $\begin{array}{l}\text { Gurubhojana [food which heavy either Gunataha (qualitatively) or } P a \text { - } \\
\text { kataha (heavy for digestion)] }\end{array}$ & + & + & & & + \\
\hline Abhishyandi Anna (one which increase secretion) & + & + & & & + \\
\hline Shita Padarth (Cold things) & + & + & + & + & + \\
\hline Ati- Himambu (Cold water) & & & & + & \\
\hline Vishtambhi (Food that causes constipation) & + & + & & & + \\
\hline Vidahi (Substance that causes burning sensation like Maricha (paper)) & + & + & + & + & + \\
\hline
\end{tabular}


Table 2: Vishishta Kalpnapradhana Ahara ${ }^{13}$

\begin{tabular}{|l|l|l|l|l|l|}
\hline Kalpnapradhana Ahara & Ch. S. & Su. S. & A.S. & A.H & M.N. \\
\hline Pishta Bhojana (Food prepared from flour) & + & & & & \\
\hline
\end{tabular}

Table 3: Vishishta Dravyapradhana Ahara ${ }^{14}$

\begin{tabular}{l|l} 
Dravyapradhana Ahara & Ch. S. \\
\hline Tila Taila (Sesamum oil) & + \\
\hline Masha (Black gram) & + \\
\hline Pinyaka (Residual part left after extraction of Sneha from seeds) & + \\
\hline Nispava (Flat pea) & + \\
\hline Jalaja Mamsa (Meat of aquatic animals) & + \\
\hline Anoopa Mamsa (Meat of animals inhabiting in marshy land) & + \\
\hline Ama Kshira (Intake of unboiled milk) & + \\
\hline Shaluka (Root or stalk of lotus) & + \\
\hline Dadhi (Curd) & + \\
\hline
\end{tabular}

Table 4: Aharavidhi Vyatikrama ${ }^{15}$

\begin{tabular}{|c|c|c|c|c|c|}
\hline Aharavidhi Vyatikrama & Ch. S. & Su. $S$. & A.S. & A.H & M.N. \\
\hline Vishamashana (Intake of irregular quantity and at irregular intervals) & + & + & & & \\
\hline Upavasa (Fast) & + & + & + & + & + \\
\hline Adhyashana (eating before digestion of previous meal & & + & & & \\
\hline
\end{tabular}

- Dietary factors, Vidahi means irritant food. The food that causes sour eructations, belching, irritation in the stomach, excess thirst, burning in the epigastric region, delayed digestion and provoke Pitta Dosha in Annavaha Srotasa is called Vidahi. Coffee, Spicy tomato sauce etc. such foods are heavy for digestion and cause inflammation (Sotha) than Sanga to Pranavaha Srotasa, hence difficulty in breathing occurs.

- The food which has slimy property, heavy for digestion, may increase moisture (Kleda) in Dhatu, Mala, and Srotasas and cause blockage in the blood vessels (Srotasa). Such foods are called Abhishyandi. They increase Kapha in Pranavaha Srotasa and causes difficulty in breathing. Nispava is Vata Vardhakal (Vitiated Vata) due to Ruksha (Dry), Kshaya (Astringent properties). Nispava, Masha, Pinyaka, Tilataila - (Kapha Karanataya Kaphajanaka Hetu). These food articles increase the Kapha Dosha present in Pranavaha Srotasa and block the channels of bronchi and causes dyspnoea.

Guru food increases the Kapha Dosha situated in Pranavaha Srotasa and cause Sanga (blockage).
- Chanakaadi Ruksha Ahara - Dry food causes Vata Prakopa. Vata Prakopa is responsible for bronchoconstriction.

- Shita Ashana Sthana Ambu Sevana Consumption of cold food and drink, exposure to cold atmosphere provokes Kapha Dosha in Pranavaha Srotasa hence dyspnoea occurs in Tamaka Shwasa. Cold drinks and Irregular food precipitate Bronchial Asthma and over intake of food and excessive fasting aggravates the symptoms of Asthma.

- Shita Gunayukta Aushadha Aharadi, some drugs and food which posses' cold potency may induce Tamaka Shwasa.

- There are some drugs (Aushadhi) like aspirin, beta adrenergic antagonist etc. can induce acute episodes of Asthma induced.

- "Jalaja Mamsa, Anoopa Mamsa, Dadhi, Ama Kshira" are included in Kapha Prakopaka Ahara takes long time to digest, and cause heaviness in body.

- Ama Kshira particularly is "Abhishyandi" (Heavy to digest and weaken digestive fire) $A g$ nimandyakara Ahara. 
All these factors cause collectively two actions. (1) Increase in Kapha and Sanga (Blockage) of Pranavaha Srotasa; (2) Vitiation of Vata directly or indirectly (due to Sanga). While explaining treatment of Tamaka Shwasa,

\section{- Viharaja Nidana}

Table 5: Vega Vidharana

\begin{tabular}{|c|c|c|c|c|c|}
\hline Vega & Ch. S. & Su. S. & A.S. & A.H & M.N. \\
\hline Kasa (Cough) & & & A.S.Su $5 / 17$ & A.H.Su 4/13 & \\
\hline Chhardi/ Vamana (Vomiting) & & & A.S.Su $5 / 21$ & A.H.Su $4 / 17$ & \\
\hline Udgara (eructations) & Ch.S. Su 7/18 & & & & M. N. 27 \\
\hline
\end{tabular}

Table 6: Others $^{16}$

\begin{tabular}{|c|c|c|c|c|c|}
\hline & Ch. S. & Su. $S$. & A.S. & A.H & M.N. \\
\hline Raja (Pollen, Dust) & + & + & + & + & + \\
\hline Dhuma (Smoke) & + & + & + & + & + \\
\hline $\operatorname{Vata}($ Wind $)$ & + & + & + & + & + \\
\hline Vyayama (Exercise) & + & + & & & + \\
\hline Gramyadhrama Sevana (Sexual indulgence) & + & + & & & + \\
\hline
\end{tabular}

\section{- Manasa Bhava ${ }^{17}$}

विषादो रोगवर्धनाम $\mid$ - च. सु. $25 / 40$

Like fear, grief, terror, Anger, envy, eagerness, tension, depression etc.

According to modern science, mainly two types of asthma are present i.e., extrinsic and intrinsic. Extrinsic (allergic) which is common in childhood and allergic in origin (Rajasa, Dhuma etc.).

- Inhalation of dust cause vitiation of Vata, hence it causes Shwasa. This refers to Tamaka Shwasa (bronchial asthma). Modern views on bronchial asthma reveals, that inhalation of house dust, pollen, mites, animal dandruff, fungal spores, feather etc., are known to decompose into smaller allergenic particles and penetrate into lower respiratory tract, histamine is released. This provokes bronchial constriction and inflammatory reaction in bronchial wall, hence dyspnoea occurs.

- Inhalation of fumes is one of the important causes of Shwasa Roga this refers to Tamaka Shwasa (bronchial asthma). The inhalation of acrid fumes,
Acharya Charaka has given the importance to Srotomarga Vishodhana (removing blockages and purify the channels) as an important measure to pacify Vata and Kapha both. cigarette smoke, strong perfumes, vapor can provoke or worsen the attacks of bronchial asthma.

- Exposure to cold weather and cold wind (airconditioned room) causes precipitation of bronchial asthma. (Sheeta Ambu, Shita-Sthana Sevana, Shitapadartha Sevana etc.)

- Physical exercise (Ativyayama) is one of the causes of Shwasa Roga. Modern observation reveals that physical exercise is one of the most common precipitating factors of acute asthma. Running produces comparatively more severe attack of asthma than walking. It is called as exercise induced asthma Any physical exertion like lifting heavy weights can trigger the asthmatic attack.

Walking longer distance (Adhvagamana) causes Shwasa Roga.

Combination of all factors like Ati-Vyayama, Adhvagamana, Atishrama etc. trigger Bronchial Asthma.

- Suppression of natural urges (Vegadharana) causes Shwasa due to Vata Prakopa Even constipation may exacerbate bronchial asthma. 
Aghataja (Traumatic/ Injury) ${ }^{18}$

Table 7: Aghataja (Traumatic/ Injury)

\begin{tabular}{|l|l|l|l|l|l|}
\hline & Ch. S. & Su. S. & A.S. & A.H & M.N. \\
\hline Marmaghata & + & + & + & + \\
\hline Kantha-Urah Pratighata & + & & & \\
\hline Karmahata & + & + & & + \\
\hline
\end{tabular}

Marmopaghata means injury or serious disturbances in function of vital organs by external or internal factors. The internal factor such as vitiation of Dosha,
Malasanchaya etc. and external factors like toxins, trauma etc. cause injury (pathological lesion) to the Srotasa causing Shwasa.

\section{Improper Panchakarma Upachara/Purifying procedures (Iatrogenic)}

Table 8: Improper Panchakarma Upachara ${ }^{19}$

Ati-Apatarana (Emaciating measures)

Shuddhi Atiyoga (Excessive indulgence in Panchakarma procedures)

Abhishyandi Upachara

\begin{tabular}{|l|l|l|l|l|}
\hline Ch.S. & Su.S. & A.S. & A.H & M.N. \\
\hline+ & & & & \\
\hline+ & + & + & + & + \\
\hline+ & & & & \\
\hline
\end{tabular}

Nidanarthakara Roga (manifestation or contraindication of other diseases) $\mathbf{2 0 , 2 1 , 2 2 , 2 3}^{2}$

Table 9: Nidanarthakara Roga

\begin{tabular}{|c|c|c|c|c|}
\hline Nidanarthakara Roga & Ch. $S^{24}$ & Su. $S^{25}$ & A.S. ${ }^{26}$ & A.H. ${ }^{27}$ \\
\hline Jwara (Fever) & + & & + & + \\
\hline Pratishyaya (Running nose/ Rhinitis) & + & & & \\
\hline Kasa (Cough) & & & + & + \\
\hline Kshata & + & & & \\
\hline Kshaya & + & + & & \\
\hline Pandu (Anaemia) & + & & + & + \\
\hline Anaha & + & & & \\
\hline Atisara / Amatisara (Diarrhoea) & + & & + & + \\
\hline Visuchika (Cholera) & + & & & \\
\hline Alasaka & + & & & \\
\hline Udavarta & + & & & \\
\hline Aamapradosha/Ama & + & + & & \\
\hline Chhardi / Vamathu (Vomiting) & + & & + & + \\
\hline Raktapitta (Haemorrhagic bleeding disorders) & + & & & \\
\hline Daurbalya (Severe weakness) & + & & & \\
\hline Apatarpana & + & & & \\
\hline Visha (Toxins) & + & & + & + \\
\hline
\end{tabular}

Jwara (Fever) Due to hypo-functioning of Agni (Digestive fire) food which is) not properly digested result in formation of immature Rasa (poorly digested chyle) as Ama. Ama is unable nourish Dhatu. Increased Doshas reach the Amashaya; they combine with Rasa Dhatu and circulate all over the body, produced fever.

Pratishyaya (Rhinitis/ Running Nose)- Pratishyaya (Rhinitis or Running nose) is a condition which the sinuses are blocked (Sanga) due Kapha Vata Prakopa and become Inflamed (Shotha).

\section{Kasa (Cough)}

कासाद् उपेक्षया श्वासो भवति | - Dalhana

कास वृध्या भवेत् श्वास: $\left.\right|^{28}$

Chronic bronchitis may turn in to Bronchial Asthma if not treated properly and timely. 


\section{Kshaya- Kshata ${ }^{29}$}

when Dhatus are not nourished properly, it leads to Ojokshaya (low immunity) and ultimately infection by pathogenic microorganisms thus causing further Kshaya and Dosha Prakopa.

\section{Pandu (Anaemia)}

Pandu is associated with a reduced amount of red blood cell (Raktadhatu Kshaya) in the blood stream i.e Rasa and Rakta Dhatus which are involved in transporting oxygen from the lungs to the body cells. Due to Dhatukshaya, there is less binding and transport of oxygen. Without enough blood cells, tissues do not receive adequate oxygen, this cause the breathlessness.

\section{Anaha}

In this condition causative factors causes the Vayu Prakopa and Srotosanga (due to Mala Sanchaya).

\section{Atisara- Visuchika - Alasaka (Diarrhea/Cholera)}

When the normal functioning of Jatharagni gets impaired due to any cause, it leads to indigestion of food and there is formation improper Ahara Rasa Dhatu and give rise to Ama. The effect of Ama can manifest in following ways. Movement of Ama towards Guda and Srotorodha lead Atisara. Moreover, if Ama moves to both sides simultaneously it may cause Visuchika. Ama has the property of Guruta and Picchilata, due to which it produces Srotorodha (stasis / blockage) in body channels leading to pathogenesis of number of diseases as per location and quantity of Ama in the body.

Udavarta: Constant intake of Guru, Vidahi, and Vistambhi, Sheeta and Rukshadi Ahara-Vihara causes Agnimandya and that leads to Ama formation, Vata vitiation and Mala Sanchaya (stasis of waste products) which thereby leads to obstruction and disruption in normal movements/ functions of Vata i.e Udavarta.

Chhardi / Vamathu (Vomiting): In the process, Vata Vayu is aggravated in Mahasrotasa and provokes the other Doshas and contaminants in the gut to move forcibly out of the body. The whole process causes excessive exertion and fatigue and breathlessness as a result.
Raktapitta (Haemorrhagic disorders): In hemorrhagic diseases/Raktapitta, there is excess / abnormal loss of blood. The condition causes less oxygen supply or hypoxia to tissues due to which breathlessness occurs.

Daurbalya: In Daurbalya, there is condition of malnourishment or Dhatukshaya in the body which causes vitiation of Dosha specially Vata Prakopa and breathlessness.

Apatarpana: Apatarpana means malnourishment also leads Dhatukshaya which cause symptom of breathlessness as explained earlier.

Visha (Toxins): Toxins (Visha) are responsible for Tridosha Prakopa, further it may lead to various pathological changes by release of various inflammatory mediators in body which are responsible for inflammation of tissues like bronchi, alveolietc' and vascular imbalance, leading to hypoxia and thus breathlessness.

Generally, nasal polyps, chronic bronchitis and altered immunological functioning are associated in these cases, which can be understood as Nidanarthakara Vyadhi.

\section{DISCUSSION}

Asthma is one of the most prevalent chronic health conditions among children and adults. It is really curse for human being as it is a chronic disorder requiring lifelong management. The prevalence of Bronchial Asthma is increasing alarmingly nowadays due to excessive pollution, overcrowding, occupational conditions, stress and poor hygiene etc. Both Ayurveda and modern medical Science agree regarding the Nidana of the disease as host factors (Nija Hetus-Dosha Dushti and Ama) and Environmental factors (Agantuj Hetus - Raja, Dhuma, Pragvata, etc.). It can be easily correlated with allergic condition. Nidana Parivarjanam plays a key role in the management strategy in both sciences.

In Tamaka Shwasa, one or more etiological factors can produce it. In Ayurvedic texts Nidanas of Tamaka Shwasa are not described separately, but the Nidana of Shwasa Roga in general are given. A detailed conceptual study how All factors are related to 
pathogenesis of Shwasa Roga has been made in current article. An attempt is made through this article to differentiate Nidanas like dietary factors (Aharaja Nidanas) with specification of properties, quality etc. and lifestyle related factors (Viharaja Nidanas) like Vega Vidharana (suppression of urges, psychological /emotional factors, iatrogenic factors like improper Panchakarma or drugs/toxins etc. The role of other diseases like Nidanarthakara Roga is also explained.

\section{CONCLUSION}

Prevalence of Bronchial Asthma is increasing alarmingly due to excessive pollution, population, occupational hazards, anxiety etc. The various etiological factors described in aetiology of this disease, act either triggering/aggravating factors, risk factors in developing attacks of asthma mostly in atopic individuals. As Nidana Parivarjana has significant role in the management of Tamaka Shwasa; for which for which proper understanding and differentiation of Nidanas is necessary. Thus, in the current article attempt is made and explain same in detail.

\section{REFERENCES}

1. Vagbhatta, Astanga Hridya, Nirmala Hindi Commentary edited by Dr. Brahmanand Tripathi, Published by Chaukhambha Sanskrit Pratisthan, Delhi, Year of Reprint 2017, Nidanasthana 1/4, Page No. 430. (Ibidem 1)

2. (Ibidem 1), Nidanasthana 1/7, Page No. 581.

3. Madhavakara, Madhav Nidana, Revised by Vijayarakshita and Kanthadatta 'Madhukosha' commentary and Vidyotini Hindi commentary by Ayurvedacharya Shri Sudarshana Shashtri, edited by Prof. Yadunandan Upadhyaya, Published by Chaukhambha Prakashana, Varanasi, Reprint Vi.Sa. 2071, Purvardha Madhukosha on 1/5, Page No. 22. (Ibidem 2)

4. Sushruta, Sushruta Samhita Part-2, Ayurvedatattva Sandipika Hindi commentary, Kaviraj Ambikadatta Shashtri, Published by Chaukhambha Bharati Academy, Varanasi, Reprint 2016, Uttarasthana 1/25, Page No. 14 (Ibidem 3)

5. (Ibidem 1), Nidanasthana 8/24, Page No. 651.

6. Agnivesha, Charaka Samhita Volume 2, revised by Charaka and Dridhbala, edited with Caraka Chandrika by Dr. Brahmananda Tripathi, Published by Chaukhambha Surbharati Prakashan, Varanasi, Year of Reprint 2014, Chikitsasthana 17/ 11 -16, Page No. 616. (Ibidem 4).

7. (Ibidem 4), Chikitsasthana 17/ 62, Page No. 624.
8. Ibidem Reference No. 6

9. Ibidem Reference No. 4

10. Vagbhatta, Ashtang Sangraha, Volume -1, edited with Hindi commentary by Kaviraja Atridev Gupta, Published by Chowkhambha Krishnadas Academy, Varanasi, Year of Reprint - 2011, Nidanasthana 4/ 3, Page No. 359. (Ibidem 5)

11. Ibidem Reference No. 1

12. Ibidem Reference No. 3

13. Ibidem Reference No. 6,4,10,1,3

14. Ibidem Reference No. 6

15. Ibidem Reference No. 6,4,10,1,3

16. Ibidem Reference No. 6,4,10,1,3

17. (Ibidem 4), Sutrasthana 25/40, Page No. 455

18. Ibidem Reference No. $6,4,10,1,3$

19. Ibidem Reference No. 6,4,10,1,3

20. (Ibidem 4), Nidanasthana 8/16, Page No. 651

21. (Ibidem 1), Nidanasthana 4/1, Page No. 454

22. (Ibidem 5), Nidanasthana 4/3, Page No. 359

23. (Ibidem 4), Chikitsasthana 17/ 12-14, Page No. 616.

24. (Ibidem 4), Chikitsasthana 17/ 12-14, Page No. 616.

25. (Ibidem 3), Uttaratantra 51, Page No. 475

26. Ibidem Reference No. 22.

27. Ibidem Reference No. 23.

28. (Ibidem 5), Nidanasthana 4/ 43 Page No. 349

29. (Ibidem 5), Nidanasthana 4/ 36 Page No. 349

\section{Source of Support: Nil Conflict of Interest: None Declared}

How to cite this URL: Tejal J. Ganvit et al: A Study Of Nidanas (Aetiological Factors) Of Tamaka Shwasa i.e. Bronchial Asthma With An Analytical View. International Ayurvedic Medical Journal \{online\} 2020 \{cited September, 2020\} Available from: http://www.iamj.in/posts/images/upload/4497 4503.pdf 